\title{
"RESTLESS LEGS" SYNDROME - THE MOST COMMON DISORDER YOU HAVE NEVER HEARD OF: A CASE REPORT
}

\author{
Jelena Stamenović
}

\begin{abstract}
Restless legs syndrome (RLS) is a chronic neurological disorder and a clearly defined pathological condition characterized by four necessary and sufficient clinical symptoms, which are at the same time essential diagnostic criteria. RLS is clinically defined by the presence of an irresistible need for legs to move, with or without the feeling of paraesthesia, worsening of symptoms during rest and improvement with activity, and the onset or worsening of subjective problems in the evening or at the night.

The onset of symptoms is most common in the fifth and sixth decade of life, with a prevalence of about $10 \%$ in the general population of Europe and North America. Women are more likely to get the disorder than men, in a $2: 1$ ratio.

A 48-year-old patient turned to a neurologist because of her feelings of "tingling, burning, and uneasiness" in her legs, which were present for 6-7 months. The neurological finding was within the framework of physiological, non-pathological focal expression. After testing, pramipexole therapy was prescribed, which caused a significant reduction in the symptoms.

Patients use variable semantic phrases to describe their symptoms, but everyone has an irresistible need for movement. Due to the heterogeneity of subjective symptoms, sensory and motor symptoms of RLS were often attributed to other illnesses, and many patients remained undiagnosed and undetected. RLS is associated with a significant reduction in quality of life, comparable to that seen in chronic diseases such as diabetes and depression. Significant unrecognized and inadequate treatment of RLS indicates that better education about this disorder is needed.
\end{abstract}

Acta Medica Medianae 2020;59(2):120-124.

Key words: restless legs syndrome, polysomnography, dopaminergic agonists

Clinical Center Niš, Clinic for Neurilogy, Niš, Serbia

Contact: Jelena Stamenović

48 Dr. Zoran Djindjić Blvd., 18000 Niš, Serbia

E-mail: j.stamenovic@yahoo.com

\section{Introduction}

The main clinical feature, or symptom of RLS or Villis-Ekbom's disease, is an unpleasant and continuous urgency for moving the leg during rest. During movement, symptoms stop, but re-occur at rest. This sensorymotor disorder significantly affects the quality of life, often leading to sleep disorders.

Past epidemiological studies have shown that the prevalence of RLS in Europe and North America is from $5 \%$ to $10 \%$ of adults in the general population. Regardless of such representation, RLS is still not recognized enough in general medical practice. Very common symptoms are attributed to polyneuropathy, peripheral circulatory disorders or neurotic disorders (1).

Diagnostic criteria involve the presence of an unbearable urgency to move legs, which is accompanied by unpleasant sensations in the legs. Symptoms worsen during rest, most often in the evening and during the night. During movement, the symptoms are partially or completely reduced (2).

In the differential diagnostic procedure polyneuropathy, peripheral circulation disorders in the legs, as well as akathisia and other psychogenic disorders should be excluded. This means that the examination of a patient with RLS must be complex and comprehensive, using modern diagnostic methods.

The RLS therapy may be pharmacological and non-pharmacological, depending on the clinical presentation of the symptoms. The pharmacological approach involves the use of iron supplements, carbidopa/levodopa, benzodiazepine sedation, hypnotics, a $2 \delta$ calcium channel ligands, dopamine agonist (ropinirole, pramipexole, and rotigotine). A nonpharmacological approach implies the application of an appropriate hygienic-dietary regime with the 
correction of daily activities and regular physical exercises.

\section{Case Report}

A 48-year-old patient, female, was sent to the neurologist because of her feelings of "tingling, burning, and uneasiness" in her legs. The problems were present for 6-7 months, with a gradual, almost imperceptible beginning. The patient could not indicate the exact date of the onset of these symptoms. Initially, the symptoms appeared mainly in the evening hours during the break at home and lasted very briefly, for several minutes with spontaneous reduction. After a few months, the feeling of uneasiness in the legs accompanied by the tightening of the feet and the lower part of legs occurred during the afternoon hours and lasted longer than 10 to 30 minutes. The problems were reduced only after getting up from the sitting position and shorter walking in the room. At that time, the patient contacted a general practitioner who prescribed benzodiazepines, whose daily dose was gradually increased to $15 \mathrm{mg}$ ( $5 \mathrm{mg}$ tablets three times daily). After a short improvement, the symptoms recurred again, and the use of benzodiazepine was discontinued.

The patient contacted a neurologist at a time when daytime activities, especially in the afternoon, were significantly damaged. The neurological finding was within the framework of physiological, nonpathological focal expression.

In the differential diagnostic procedure, basic laboratory analyzes and differential blood counts were made, with a proper finding. EMNG of the upper and lower extremities, ultrasound examination of blood vessels of the leg and MR of endocranium did not show pathological changes.

Per exclusionem, she was diagnosed with RLS, as all four clinical diagnostic criteria were met.

After examination, pramipexole therapy was prescribed, which caused a significant reduction in the symptoms. The initial dose was $0.25 \mathrm{mg}$ of pramipexole daily, in the evening. After three months the dose was increased to $0.50 \mathrm{mg}$ of pramipexole in the evening, due to the recurrence of problems that were very mild and short duration, mainly in the evening or during a longer afternoon rest. After increasing the therapeutic dose of pramipexole, there was a complete reduction in the symptoms. The next control neurological examination was scheduled in three months. If these problems occurred again, a gradual increase in therapeutic doses of pramipexole was planned.

\section{Discussion}

Since the 1960s, the diagnostic criteria of the RLS have undergone several revisions and improvements, including the earliest, informal Ekbom's criteria from 1960. Based on the previous diagnostic criteria, the four basic diagnostic criteria of RLS published by the International Group for the Study of Restless Legs Syndrome (IRLSSG) in 2003 emphasized the importance of the urge to move legs in the diagnosis of RLS (2).

Diagnostic criteria of the International Restless Legs Syndrome Group (IRLSSG) are:

1. Foot movement, usually accompanied or caused by an unpleasant and uncomfortable feeling in the legs. Sometimes the urge for movement is present without the discomfort of legs, and sometimes the hands or other parts of the body may be involved.

2. An irresistible need for movement or unpleasant sensations begins or deteriorates during a period of rest or inactivity, such as sitting or lying down.

3. Unpleasant sensations or movements are partially or completely reduced during walking or stretching, at least as long as this activity lasts.

4. Movement or unpleasant feelings are more pronounced in the evening or at night than during the day, or occur only in the evening or at night. When the symptoms are significantly incapacitating, aggravation during the night does not have to be more pronounced in relation to daytime symptoms, but must be previously present.

A differential diagnostic procedure is important to exclude other medical or behavioral conditions accompanied by cramps in the legs or legs movements.

Support Criteria:

1. Family anamnesis for RLS

2. Positive therapeutic response to the use of dopaminergic drugs

3. Polysomnographic examination of periodic movements of limbs during wakefulness or sleeping (1).

RLS is thought to be a complicated sensorimotor syndrome that may be associated with changes in sensorimotor integration. The mechanism of such changes is still not clear. The aim of the study, conducted by Lin and associates in 2018, was to investigate the sensorimotor integration in patients with RLS through transcranial magnetic stimulation of motor evoked potentials (TMS-MEPS), preceded by peripheral electrical stimulation. The results of the study indicate increased motor cortical excitability of the leg and impaired sensorimotor integration in people with RLS. This disorder is thought to occur at the cortical level (3).

Recent literature suggests that the pathophysiology of RLS includes impaired cortical sensorimotor integration and the presence of hyperexcitability of the cortical-striatal-thalamic-cortical network, with the consequent hyperexcitability of spinal motor neurons. Intramuscular injection of botulinum toxin type $A$, in addition to muscle relaxation which causes inhibition of acetylcholine, significantly reduces the discharge of muscle spindles. There is evidence that intramuscularly injected botulinum toxins can reach the spinal cord from the site of injection and directly affect the spinal cord neurons. A study by Mittal and associates in 2018 showed that botulinum toxin type $A$ can reduce the severity of symptoms within six weeks. The quality of life of 
RLS patients can be improved up to six weeks after injection, and pain and discomfort are reduced over four weeks (4).

The genetic contribution to the development of RLS remains poorly explained. In 2007, the first large-scale genome wide association study identified three genomic regions associated with RLS. MEIS1, BTBD9 and MAP2K5/SKOR1 are genes located within these loci and their association with RLS was subsequently confirmed in a number of follow up genome wide association studies. Catoire et al. (2018) published the results of a study that directly link MEIS1 and SKOR1, two significantly associated genes with RLS and also prioritized SKOR1 over MAP2K5 in the RLS associated intergenic region of MAP2K5/SKOR1 (5).

RLS therapy is primarily pharmacological and non-pharmacological treatment has limited impact. Harrison et al. (2018) conducted a study that examined the effects of exercise for relaxation and stress relief in people with RLS. Physical exercises for stretching and fatigue of the lower extremities were performed at weekly intervals, with an estimate at the end of each interval. No significant differences were observed between the group that had physical exercises and control groups in the sixth week. Significant improvements have been recorded over time in all groups (6).

In a differential diagnostic procedure, it is important to distinguish RLS from other conditions and diseases that may have similar symptoms. Disorders of venous circulation are often accompanied by pain and cramps in the legs, but they do not have a circadian rhythm like RLS symptoms. Also, venous circulatory disorders appear with the changes in the skin, without improving with the use of dopaminergic therapy. Akathisia associated with the use of neuroleptics is characterized by the feeling of internal anxiety and the inability to rest during the day. In akathisia, movements occur on different parts of the body, without the subsequent feeling of relief. The symptoms of polyneuropathy that are characterized by painful burning in the extremities should be different from the symptoms of the RLS. Lumbosacral radiculopathy mainly has unilateral sensory paraesthesias followed by painful sensitivity in the lower part of the spine and along the leg (1).

Pharmacological treatment involves dopaminergic medication (pramipexole, ropinirole and rotigotine) as first-line therapy. The therapeutic use of pregabalin is also gaining in importance. Opioids have shown efficacy in the treatment of RLS symptoms, but their adverse effects and the possibility of abuse significantly limit their use. Other pharmacological approaches include the addition of iron supplements in anemic patients, the use of some anticonvulsants and benzodiazepines. A very common comorbid disorder in RLS is depression. But treatment of depression should be cautious as selective serotonin reuptake inhibitors and tricyclic antidepressants may adversely affect the symptoms of RLS. The use of bupropion was recommended because no adverse effects were observed in its use (2). In a study carried out by Roshi et al. (2018), a statistically significant improvement in the activity of the daily living, with clonazepam compared to nortriptyline was demonstrated. Nortriptyline significantly improved patients' mood during eight weeks of administration (7).

After completing the differential diagnostic procedure and setting the exact diagnosis of RLS, treatment should be initiated using the dopamine agonist at the lowest possible dose, most often in the evening. If depressive symptomatology is present, antidepressant therapy may also be included. An adequate hygienic and diet regime, as well as adequate physical activity, is very important.

\section{Conclusion}

RLS is a relatively common disorder in clinical practice, but it is still insufficiently recognized by the doctors. Considering that it significantly affects daily activities, it is important to apply adequate therapy that is available. It is necessary to pay more attention to the symptoms and clinical presentation of this syndrome in order to provide better quality of life for the patients. 


\section{References}

1. Kwatra V, Muhammad AK, Quadri SA, Cook ST. Differential Diagnosis and Treatment of Restless Legs Syndrome: A Literature Review. Cureus 2018;10(9): e3297. [CrossRef] [PubMed]

2. Guo S, Huang J, Jiang $\mathrm{H}$, Han $\mathrm{C}$, Jie Li, Xiaoyun $\mathrm{Xu}$, et al. Restless Legs Syndrome: From Pathophysiology to Clinical Diagnosis and Management. Front Aging Neurosci 2017;9:171. [CrossRef] [PubMed]

3. Lin $Y$, Wang $Y$, Zhan S, Ding $Y$, Hou $Y$, Wang $L$, et al. Impaired Sensorimotor Integration in Restless Legs Syndrome. Front Neurol 2018;9:568.

[CrossRef] [PubMed]

4. Mittal OS, Machado D, Richardson D, Dubey D, Jabbari B. Botulinum Toxin in Restless Legs Syndrome - A Randomized Double-Blind Placebo-Controlled Crossover Study. Toxins 2018;10(10):401.

[CrossRef] [PubMed]
5. Catoire H, Sarayloo F, Mourabit AK, Apuzzo S, Grant $A$, Rochefort $D$, et al. A direct interaction between two Restless Legs Syndrome predisposing genes: MEIS1 and SKOR1. Sci Rep 2018;8(1):12173.

[CrossRef] [PubMed]

6. Harrison EG, Keating JL, Morgan P. Novel Exercises for Restless Legs Syndrome: A Randomized, Controlled Trial. J Am Board Fam Med 2018;31(5):783-94. [CrossRef] [PubMed]

7. Roshi, Tandon RV, Mahajan A, Sharma S, Khajuria V. A Prospective, Randomized, Open-Label Study Comparing the Efficacy and Safety of Clonazepam versus Nortriptyline on Quality of Life in $40+$ Years old Women Presenting with Restless Leg Syndrome. ] Midlife Health 2018;9(3):135-9. [CrossRef] [PubMed] 


\title{
SINDROM "NEMIRNIH NOGU" - NAJČEŠĆI POREMEĆAJ ZA KOJI NIKADA NISTE ČULI: PRIKAZ SLUČAJA
}

\begin{abstract}
Jelena Stamenović
Klinički centar Niš, Klinika za neurologiju, Niš, Srbija

Kontakt: Jelena Stamenović

Bulevar dr Zorana Đinđića 48, 18000 Niš, Srbija

E-mail: j.stamenovic@gmail.com

Sindrom "nemirnih nogu" (RLS) je hronični neurološki poremećaj i jasno definisano patološko stanje, koje karakterišu četiri neophodna i dovoljna klinička simptoma, koji su ujedno i osnovni dijagnostički kriterijumi. RLS je klinički definisan prisustvom neodoljive potrebe za pokretanjem nogu, sa osećajem ili bez osećaja parestezija, pogoršanjem simptoma tokom odmora i poboljšanjem tokom aktivnosti, kao i početkom ili pogoršanjem subjektivnih tegoba uveče ili tokom noći. Početak simptoma je najčešći u petoj i šestoj deceniji života, sa prevalencijom od oko $10 \%$ u opštoj populaciji Evrope i Severne Amerike. Žene oboljevaju češće od muškaraca, u odnosu $2: 1$.

Četrdesetosmogodišnja bolesnica obratila se neurologu zbog osećaja "trnjenja, peckanja i nelagodnosti" u nogama, koji su prisutni 6 - 7 meseci. Neurološki nalaz bio je bez patološkog fokalnog ispoljavanja. Nakon ispitivanja, propisana je terapija pramipeksolom, što je dovelo do značajne redukcije tegoba.

Bolesnici koriste varijabilne semantičke fraze za opisivanje simptoma, ali svima je zajednička neizdrživa potreba za kretanjem. Zbog heterogenosti subjektivnih tegoba, senzomotorni simptomi RLS-a često se pripisuju drugim bolestima, a mnogi bolesnici ostali su nedijagnostikovani. RLS je povezan sa značajnim smanjenjem kvaliteta života, uporedivim sa onim kod hroničnih bolesti, kao što su dijabetes i depresija. Značajno neprepoznavanje i neadekvatan tretman RLS-a pokazuju da je potrebna bolja edukacija o ovom poremećaju.
\end{abstract}

Acta Medica Medianae 2020;59(2):120-124.

Ključne reči: sindrom nemirnih nogu, polisomnografija, dopaminergički agonisti 